\title{
Analisis Penerapan Full Day School dalam Membentuk Karakter Religius Siswa Sekolah Dasar
}

\author{
Wella Rezki ${ }^{1}$ \\ ${ }^{1}$ SDN 09/III Baru Lempur, Jambi, Indonesia
}

\begin{tabular}{l} 
Info Artikel \\
\hline Riwayat Artikel: \\
Received Jan 7, 2020 \\
Revisied Jan 17, 2020 \\
Accepted Jan 28, 2020 \\
\hline
\end{tabular}

\section{Kata Kunci:}

Full Day School

Karakter

Religious

\begin{abstract}
ABSTRAK
Tujuan Penelitian: Usia sekolah dasar merupakan pondasi peserta didik dalam mengembangkan kemampuan berpikir melalui kemampuan metakognisi yang baik. Metakognisi merupakan kesadaran seseorang dalam berpikir mengenai pemikiran itu sendiri. Penelitian ini bertujuan untuk menganalisis penerapan dari full day school. Dalam penelitian ini berdasarkan pengelompokkannya adalah menggunakan sumber primer. Data primer dalam penelitian ini berupa data hasil observasi dan data hasil wawancara
\end{abstract}

Metodologi: Pendekatan dalam penelitian ini adalah pendekatan kualitatif. Peneliti memilih sampel sumber data yang bersifat Snowball Sampling. Peneliti menggunakan analisis data model Miles and Huberman sebagai acuan untuk menganalisis semua data yang diperoleh oleh peneliti. Dengan adanya penerapan full day school yang diterapkan di Sekolah Dasar Negeri 47/ Kota Jambi sekolah dapat memantau kegiatan keagamaan siswa. Jenis penelitian ini adalah penelitian fenomenologi

Temuan Utama: Full day school merupakan metode bagus untuk meningkatkan kemampuan siswa dan membentuk karakter siswa. Dengan waktu delapan jam perhari di sekolah, siswa akan mendapatkan kesempatan untuk mengembangkan bakat dan kemampuannya dibidang pendidikan dengan bantuan guru dan tenaga pendidik lainnya.

Copyright (C) 2020 Cahaya Ilmu Cendekia Publisher. All rights reserved.

\section{Corresponding Author:}

Wella Rezki,

SDN 09/III Baru Lempur,

E mail: wellarezki123@gmail.com

\section{PENDAHULUAN}

Pendidikan adalah upaya menciptakan sumber daya manusia yang berkualitas, sehingga penting untuk meningkatkan pendidikan di Indonesia [1-2]. Full day school merupakan sebuah sistem pembelajaran yang dilakuan dalam waktu sehari penuh dan juga merupakan program pemerintah, program ini menerapkan sistem pembelajaran secara intensif yaitu dengan memberikan waktu khusus selama lima hari untuk pendalaman materi dan satu hari untuk kegiatan ekstrakulikuler [3]. Full day school juga dapat diartikan dengan suatu program yang telah dirintis oleh beberapa sekolah yang ada di Indonesia, salah satunya adalah di Kota Jambi. Dengan tersedianya waktu yang cukup lama dilingkungan sekolah siswa perlahan-lahan akan terbiasa dengan kehidupan yang mandiri [4-5], dan menumbuhkan sikap kebersamaan dan kesadaran beribadah serta sikap positif lainnya yang menjadikan siswa menjadi lebih baik [6-7]. Program tersebut dapat digunakan untuk mengembangkan kreativitas dan bakat yang dimiliki oleh siswa. Dalam penerapannya, pelaksanaan program full day school memadukan sistem pengajaran Islam secara intensif, yaitu dengan memberi tambahan waktu khusus untuk pendalaman keagamaan siswa. Biasanya jam tambahan tersebut dialokasikan pada jam setelah shalat zuhur sampai shalat ashar sehingga praktis, sekolah model ini masuk 
pukul 07.00 WIB pulang pukul 15.15 WIB [8]. Pelaksanaan full day school merupakan salah satu alternatif untuk mengatasi berbagai masalah pendidikan, baik dalam prestasi maupun dalam hal moral atau akhlak [9]. Dengan mengikuti full day school, orang tua dapat mencegah dan menetralisir kemungkinan dari kegiatankegiatan anak yang menjerumus pada kegiatan yang negatif.

Salah satu alasan para orangtua memilih dan memasukkan anaknya ke full day school adalah dari segi edukasi siswa. The move to strengthen the proficiency level of the students has taken place through several policies carried out by the Ministry of Education [10-11]. Melalui penerapan full day school, pemerintah berupaya untuk memenuhi kebutuhan masyarakat, seperti orang tua siswa yang sibuk bekerja dan harapan terselenggaranya pendidikan yang berkualitas, yang mengutamakan penanaman nilai-nilai karakter dalam diri siswa [12-13]. The School leaving grades reflect the dimension of the student characteristics and original behaviour [14-15]. Menurut ref [14] terdapat 18 Nilai-nilai karakter dalam pendidikan budaya bangsa yang harus ditanamkan pada peserta didik yaitu religius, jujur, toleransi, disiplin, kerja keras, kreatif, mandiri, demokratif, rasa ingin tahu, semangat kebangsaan, cinta tanah air, menghargai prestasi, bersahabat atau komunikatif, cinta damai, gemar membaca, peduli lingkungan sosial, dan tanggung jawab. Karakter merupakan akhlak atau kepribadian yang membedakan seorang individu dengan individu lainnya. Dari 18 nilai-nilai karakter salah satunya terdapat karakter religius. Karakter religius diartikan dengan sikap dan perilaku dalam melaksanakan ajaran agama yang dianutnya, toleran terhadap pelaksanaan ibadah agama lain, serta hidup rukun dengan pemeluk agama lain.

Peneliti melakukan studi pendahuluan untuk mengetahui hal-hal relevan terkait masalah yang akan diteliti. Studi pendahuluan dilaksanakan di September 2018 di Sekolah Dasar Negeri 47/IV Kota Jambi. Dalam melakukan studi pendahuluan peneliti mengamati tentang penerapan full day school, wawancara dengan kepala sekolah, guru serta melakukan wawancara dengan siswa. Dari hasil studi pendahuluan, peneliti mendapatkan beberapa hal penting yang membuat peneliti semakin tertarik untuk melakukan penelitian terkait hal tersebut. Hal tersebut yaitu 1) pada saat peneliti melakukan pengamatan dari adanya penerapan full day school yang diterapkan di Sekolah Dasar Negeri 47/IV Kota Jambi, Pada saat jam sholat dzuhur telah tiba, ada saja hal unik yang dilakukan oleh siswa, ada yang bergegas untuk ke musholla sekolah untuk melaksanakan sholat dzuhur berjamaah dan ada juga siswa yang menyetor hapalan-hapalan surat pendek kepada guru agama. 2) berdasarkan hasil wawancara dengan kepala sekolah dan guru dengan adanya penerapan full day school yang telah diterapkan pada tahun 2017 di Sekolah Dasar Negeri 47/IV Kota Jambi, peneliti mendapatkan informasi bahwa dengan adanya penerapan full day school sekolah membiasakan siswa untuk melakukan sholat dzuhur berjamaah, menyetor hapalan-hapalan surat pendek, serta menyediakan Taman Pendidikan AL-Qur'an untuk siswa. 3) dari hasil wawancara dengan siswa, mereka mengemukakan bahwa dengan adanya penerapan full day school mereka bisa melakukan sholat dzuhur berjamaah, pembentukan akhlak dan akidah serta dapat mengembangkan potensi yang dimiliki melalui ekstrakulikuler. Berdasarkan hasil observasi yang peneliti lakukan di SD 47 Kota Jambi adalah Sekolah tersebut telah menerapkan program full day school, dan sudah cukup lama membiasakan peserta didiknya untuk melaksanakan karakter religius atau keagamaan. Berdasarkan permasalah yang terdapat pada latar belakang masalah diatas, maka peneliti bermaksud melakukan penelitian dengan judul "Penerapan Full Day School Dalam Membentuk Karakter Religius Siswa Sekolah Dasar”.

Seiring dengan dinamika kehidupan yang kian menuntut kecepatan, ketepatan, kewaspadaan, perkembangan intelektual, emosional, spiritual dan kreatifitas siswa, metode konvensional dirasa belum dapat memenuhi kebutuhan pendidikan di masa sekarang dan mendatang sehingga muncullah konsep pendidikan baru yang dinamakan full day school [15-16]. Full day school merupakan sebuah sistem pembelajaran yang dilakuan dalam waktu sehari penuh dan juga merupakan program pemerintah, program ini menerapkan sistem pembelajaran secara intensif yaitu dengan memberikan waktu khusus selama lima hari untuk pendalaman materi dan satu hari untuk kegiatan ekstrakulikuler [8]. Full day school yang dimaksudkan untuk meningkatkan pencapaian tujuan pendidikan dan pembelajaran dengan penambahan jam pelajaran agar siswa mampu mendalami sebuah mata pelajaran dengan jatah waktu yang propersional selama sehari penuh [17-18].

Program full day school sendiri ialah sebuah sistem pembelajaran yang dilaksanakan dalam waktu sehari penuh. Program ini menerapkan sistem pembelajaran secara intensif yaitu dengan memberikan waktu khusus selama lima hari untuk pendalaman materi dan satu hari ekstrakulikuler. Pendapat lain menjelaskan bahwa full day school merupakan sekolah sepanjang hari dimana proses kegiatan belajar mengajar dilakukan dari pagi hari hingga sore hari yaitu pukul 06.45 WIB, termasuk waktu istirahat [9]. Keberadaan full day school dinilai menguntungkan, karena anak-anak memiliki watu belajar yang lebih banyak dibandingkan waktu bermain yang bermuara pada produktivitas yang tinggi sehingga akan menunjukkan sikap positif dan terhindar dari pergaulan yang menyimpang [19-20]. Namun, program full day school memberikan efek lain diantaranya menjadikan siswa kurang berinteraksi dengan lingkungan keluarga, berkurangnya waktu bermain

JBER. Vol. 1, No. 1, Januari 2020: $21-28$ 
siswa, siswa banyak kehilangan waktu belajar dirumah dan belajar tentang hidup bersama keluarganya [12]; [14].

\section{METODE PENELITIAN}

Pendekatan dalam penelitian ini adalah pendekatan kualitatif. Menurut ref [21-23] metodologi kualitatif merupakan prosedur penelitian yang menghasilkan data deskriptif berupa kata-kata tertulis atau lisan dari subjek yang diamati. Pendekatan kualitatif digunakan untuk mendeskripsikan penerapan full day school dalam membentuk karakter religius. Jenis penelitian ini adalah penelitian fenomenologi.

Dalam penelitian ini bertujuan untuk menganalisis penerapan dari full day school. Analisis yang dilakukan dengan data yang valid dan sesuai dengan objek penelitian. Dalam penelitian ini berdasarkan pengelompokkannya adalah menggunakan sumber primer. Menurut ref [24-26] sumber primer adalah sumber data yang langsung memberikan data kepada pengumpul data. Data primer dalam penelitian ini berupa data hasil observasi dan data hasil wawancara. Informasi dan sumber data yang dapat diperoleh dalam penelitian ini diantaranya Kepala Sekolah, guru dan siswa SD 47 Kota Jambi.

Peneliti memilih sampel sumber data yang bersifat Snowball Sampling. Snowball sampling adalah teknik pengambilan sampel sumber data, yang awalnya berjumlah sedikit kemudian lama-lama menjadi besar sampai ketemu masalahnya. Dalam penentuan sampel, pertama-tama dipilih satu atau dua orang sampel, tetapi karena dengan dua sampel ini belum merasa lengkap terhadap data yang diberikan maka peneliti mencari orang lain yang dipandang lebih tahu dan dapat melengkapi data yang telah diberikan oleh dua orang sampel sebelumnya. Begitu seterusnya sehingga jumlah sampel semakin banyak [27].

Peneliti menggunakan analisis data model Miles and Huberman sebagai acuan untuk menganalisis semua data yang diperoleh oleh peneliti. Menurut ref [14]; [28]; [29] menjelaskan bahwa analisis data kualitatif dilakukan secara interaktif dan berlangsung secara terus menerus sampai tuntas, sehingga datanya sampai jenuh. Adapun langkah-langkah dalam analisis data yang dilakukan oleh peneliti adalah sebagai berikut:

\section{Data Reduction (Reduksi Data)}

Mereduksi data berarti merangkum, memilah hal-hal pokok, memfokuskan pada hal-hal yang penting, dicari tema dan polanya dan membuang yang tidak penting.

2. Data Display (Penyajian Data)

Menyajikan data yang paling sering digunakan dalam penelitian kualitatif adalah dengan teks yang bersifat naratif Miles and Huberman

3. Verivication (Penarikan Kesimpulan)

Langkah terakhir adalah penarikan kesimpulan. Kesimpulan dalam penelitian kualitatif bisa berupa temuan baru yang sebelumnya belum pernah ada.

\section{HASIL DAN PEMBAHASAN}

Hasil observasi yang peneliti lakukan di Sekolah Dasar Negeri 47/IV Kota Jambi sebagai berikut:

1) merayakan hari besar keagamaan seperti Isra Mi'raj, tahun baru Islam dan hari besar keagamaan lainnya.

Pada tanggal 10 September 2018 Sekolah Dasar Negeri 47/IV Kota Jambi merayakan tahun baru islam $1440 \mathrm{H}$, yang diikuti dari kelas 3 sampai kelas 6 dengan jumlah siswa yang hadir sebanyak 878 dari jumlah siswa keselurahan sebanyak 1.195. Adapun tujuan dari perayaan tahun baru islam $1440 \mathrm{H}$ yaitu mengenalkan siswa terhadap kalender islam dan memupuk jiwa islami dan kemandiriin siswa. pada perayaan ini siswa mengenakan seragam profesi sesuai dengan cita-citanya tujuannya agar siswa termotivasi untuk lebih giat belajar mencapai cita-cita.

2) memiliki fasilitas yang dapat digunakan untuk beribadah, seperti tersedianya Satu Musholla untuk ibadah agama islam melakukan Sholat berjamaah dan tersedianya satu ruangan tempat pendidikan AL-Qur'an serta tersedia tempat beribadah untuk agama kristen untuk pembacaan al-kitab dan kebaktian.

3) memberikan kesempatan kepada semua siswa untuk beribadah baik agama islam maupun agama kristen.

4) siswa berdo'a sebelum dan sesudah pembelajaran

Proses pengambilan data dengan menggunakan metode wawancara yang diajukan kepada Kepala Sekolah, Guru, dan Siswa. Sebelum melakukan wawancara yang diawali dengan penentuan waktu dan tempat untuk melaksanakan wawancara agar wawancara yang dilakukan efektif dan data yang diperoleh lebih mendalam.

\section{Hasil Wawancara Dengan Kepala Sekolah}


Pertanyaan $\quad$ : Bagaimana latar belakang adanya penerapan Full Day School di Sd 47 Kota Jambi ?

Jawab : Merupakan program pemerintah yang dicetuskan pada tahun 2017. Sekolah Dasar Negeri 47/IV Koto jambi merupakan salah satu piloting yang ditunjuk oleh pemerintah pusat untuk melaksanakan program penguatan karakter sejak tahun 2017. Full Day School ini merupakan bagian dari penguatan karakter, di Sekolah Dasar Negeri 47/IV kota jambi menerapkan 5 karakter yaitu Religius, Mandiri, Gotong Royong, Nasionalis dan integritas dan sudah ada SK dari pemerintah. Karena juga melihat karakter dari anak sekarang mulai dari sopan santun, dan religius. Dari adanya penerapan full day school, sekolah dapat memantau sholat bagi agama islam dan bagi agama kristen dapat memantau untuk pembacaan al-kitab

Pertanyaan $\quad$ : Kapan Diterapkan Sistem Full Day School?

Jawab : Full day school diterapkan di Sekolah Dasar Negeri 47/IV Kota Jambi yaitu pada Tahun 2017

Pertanyaan : Bagaimana Bentuk Penerapan Full Day School Dalam Karakter Religius Siswa Sekolah Dasar 47/IV Kota Jambi?

Jawab : Dengan adanya penerapan Full Day School di Sekolah Dasar Negeri 47/IV Kota Jambi sekolah dapat memantau siswa dalam kegiatan keagamaan baik agama islam maupun agama kristen. Dari segi agama islam sekolah dapat memantau dari sholat Dzhuhur, Pengajian Anak, dan bagi agama kristen sekolah dapat memantau dari kebaktian, pembacaan Al-kitab, dan pendalaman ilmu agama.

Pertanyaan : Apa tujuan dari semua upaya dan kegiatan yang dilakukan oleh guru tentang pembentukan sikap islami siswa?

Jawab : Tujuannya ialah untuk membentuk siswa Sekolah Dasar Negeri 47/IV Kota Jambi menjadi siswa yang memiliki kepribadian muslim atau sikap islami, yang harapan kedepannya siswa akan menjadi anak yang memiliki pribadi muslim yang kaffah yang setiap gerak geriknya mencerminkan seorang muslim yang baik dan taat serta mampu mengamalkan ajaran islam dimanapun dan menjadi apapun nantinya.

Pertanyaan : Bagaimana Dampak Dari Penerapan Full School di Sekolah Dasar Negeri 47/IV Kota Jambi?

Jawab : dampak dari full day school dari segi karakter religius yaitu sekolah bisa memantau kegiatan keagamaan siswa, baik yang beragama islam maupun kristen.

2. Hasil Wawancara Dengan Guru

Pertanyaan $\quad$ : Bagaimana latar belakang adanya penerapan Full Day School di Sd 47 Kota Jambi ?

Jawab : latar belakang adanya penerapan Full Day School di Sekolah Dasar Negeri 47/IV Kota Jambi biasanya siswa pulang jam 12.05 kemudian siswa banyak menghabiskan waktunya dirumah kemudian orang tua dilingkungan kita itu pekerja kantor jadi mereka tidak ada pengawasan dirumah. Jadi kebanyakan permintaan orangtua siswa, supaya anak-anaknya berada disekolah sekitar sampai pukul 15.10 jadi orang tua merasa lebih aman. Kalau dari guru karena di sini ada program penguatan karakter dan itu merupakan bagian dari full day school.

Pertanyaan : Kapan Diterapkan Sistem Full Day School?

Jawab : Full day School diterapkan kira-kira sudah berjalan selama 2 tahun, jadi itu memang kebijakan dari pemerintah dan banyak SD rujukan yang sudah banyak menerapkan full day school dan pertama kali.

Pertanyaan : Bagaimana Bentuk Penerapan Full Day School Dalam Karakter Religius Siswa Sekolah Dasar 47/IV Kota Jambi?

Jawab : Dengan adanya penerapan Full Day School di Sekolah Dasar Negeri 47/IV Kota Jambi saya pribadi dapat memantau siswa dalam kegiatan keagamaan baik agama islam maupun agama kristen. Sebelum adanya penerapan full day school di terapkan disini guru-guru tidak bisa memantau kegiatan keagamaan siswa karena siswa pulang jam 12.05.

Pertanyaan : : Bagaimana Upaya Guru dalam Pembentukan Sikap Islami Kepada Siswa?

Jawab : Upaya guru dalam pembentukan sikap islami siswa yang pertama yaitu keteladanan karena dengan memberikan keteladanan yang baik kepada siswa maka siswa akan termotivasi untuk melakukan perbuatan baik. Kedua pembiasaan seperti pembiasaan mengucapkan salam atau menjawab salam setiap bertemu. Ketiga menciptakan suasana yang kondusif dan keempat memberikan reguran langsung apabila siswa melakukan tindakan yang tidak sesuai dengan norma, adab dan ajaran islam.

JBER. Vol. 1, No. 1, Januari 2020: 21 - 28 
Pertanyaan : Bagaimana Dampak Dari Penerapan Full School di Sekolah Dasar Negeri 47/IV Kota Jambi?

Jawab : Dampak dari penerapan full day school yaitu sekolah dapat memantau kegiatan keagamaan siswa. Sebelum diterapkan full day school siswa pulang jam 12.05 jadi sekolah tidak tau apakah siswa melakukan kegiatan keagamaan seperti sholat, pengajian, membaca al-kitab dan kebaktian untuk agama kristen.

Pertanyaan : Apa Saja Faktor Penghambat Penerapan Full Day School Dalam Membentuk Karakter Religius Siswa?

Jawab : Faktor penghambat yaitu sarana dan prasarana.

3. Hasil Wawancara Dengan Siswa

Pertanyaan : Apa yang kamu rasakan dengan adanya penerapan Full Day School di Sekolah Dasar Negeri 47/IV Kota Jambi?

Jawab : : Senang Buk, karena bisa bertemu teman dan guru-guru juga

Pertanyaan : Apakah ada pembelajaran pendidikan karakter terutama pendidikan karakter religius di kelas?

Jawab : Ada kak, kami biasanya setiap hari selasa menyetor hapalan surat-surat pendek, dan juga setiap hari kami sholat dzuhur bersama-sama.

Pertanyaan : Pembiasaan seperti apa yang ada disini untuk membentuk karakter religius?

Jawab : Pembiasaannya seperti sholat dzuhur buk dan siswa dibiasakan sholat dhuha juga

Pertanyaan : Apa dampak yang ditimbulkan dari adanya penerapan full day school?

Jawab : Dampaknya adalah kami biasanya pulang jam 12.30 tapi sekarang kami pulangnya jam 15.00 buk, terus dulu tidak ada sholat berjamaah tapi sekarang sudah ada buk.

Berdasarkan Hasil Penelitian Yang Diperoleh Mengenai Analisis Penerapan Full Day School Dalam Membentuk Karakter Religius Siswa Sekolah Dasar. Full day school merupakan sebuah sistem pembelajaran yang dilakuan dalam waktu sehari penuh dan juga merupakan program pemerintah, program ini menerapkan sistem pembelajaran secara intensif yaitu dengan memberikan waktu khusus selama lima hari untuk pendalaman materi dan satu hari untuk kegiatan ekstrakulikuler. Menurut ref [1] Full day school merupakan metode bagus untuk meningkatkan kemampuan siswa dan membentuk karakter siswa. Dengan waktu delapan jam perhari di sekolah, siswa akan mendapatkan kesempatan untuk mengembangkan bakat dan kemampuannya dibidang pendidikan dengan bantuan guru dan tenaga pendidik lainnya. Full day school diharapkan mampu meminimalisir kegiatan negatif, dapat membentuk akhlak yang baik dan menanamkan nilai-nilai yang positif serta full day school juga efektif dalam mengaplikasikan kemampuan siswa dalam segala hal, seperti yang mencakup semua ranah baik kognitif, afektif maupun psikomotorik dan juga kemampuan bahasa asing.

Full day school adalah program sekolah di mana proses pembelajarannya dilaksanakan sehari penuh di sekolah. Dengan kebijakan seperti ini, maka waktu dan kesibukan anak-anak lebih banyak dihabiskan di lingkungan sekolah dari pada di rumah, atau dapat juga dikatakan salah satu karya cerdik para pemikir atau praktisi untuk menyiasati minimnya kontrol orang tua terhadap anaknya diluar jam-jam sekolah formal. Dalam penerapan full day school ini siswa memperoleh banyak keuntungan secara akademik, tentu saja lamanya waktu belajar juga merupakan salah satu dari dimensi pengalaman anak. Sekolah Dasar Negeri 47/IV Kota Jambi merupakan salah satu sekolah rujukan yang telah menerapkan Full day school sejak tahun 2017 dengan tujuan sekolah yaitu meraih standar minimal 7,5 serta memenuhi standar nasional pendidikan secara maksimal dengan memberikan waktu yang panjang dan dapat diisi dengan berbagai kegiatan maka siswa akan mendapatkan kesempatan yang luas untuk mengembangkan bakatnya dibidang pendidikan dengan bantuan guru dan tenaga pendidik lainnya.

Berdasarkan wawancara terkait latar belakang penerapan full day school di Sekolah Dasar Negeri 47/IV Kota Jambi Selain merupakan program pemerintah pihak sekolah juga ingin memberikan siswa skill tentang keagamaan khususnya tentang pendidikan karakter. Full day school ini sangat diminati dikalangan masyarakat atau orang tua peserta didik yang pada umumnya masyarakat modern dan mempunyai kesibukan diluar rumah atau sebagai pekerja kantoran sehingga perhatian terhadap orang tua khususnya siswa sangat kurang. Pertama, meningkatnya jumlah orangtua (parent-career) yang kurang memberikan perhatian kepada anaknya, terutama yang berhubungan dengan aktivitas anak setelah pulang dari sekolah Kedua, perubahan sosial budaya yang terjadi dimasyarakat, dari masyarakat agraris menuju ke masyarakat industri. Perubahan tersebut jelas berpengaruh pada pola pikir dan cara pandang masyarakat [17][30]. Oleh karena itu, Sekolah Dasar Negeri 47/IV Kota Jambi menerapkan full day school yang dapat menjadi solusi alternatif untuk pihak orang tua yang umumnya pekerja kantoran. 
Full day school dilaksanakan tujuannya adalah untuk pembentukan karakter seperti baca tulis alQur'an serta ada tuntutan menghapfal doa sehari-hari dan setoran surat-surat pendek, serta surat yasin dan tahlil dan bimbingan sholat. Dengan diadakan sistem full day school dapat memanfaatkan waktu dengan sebaik-baiknya, maka dapat memacu siswa untuk lebih giat belajar dan dapat menanamkan nilai-nilai positif serta pembentukan karakter. Adapun dampak dari penerapan full day school, dampak yang ditimbulkan ialah dalam kehidupan sehari-hari, dalam pergaulan sosial juga akan bagus dalam arti tindakan dan perbuatannya yang sopan[31][32][33][34]. Diakibatkan dari hati yang sering dibuat untuk hal-hal positif. Siswa yang berpengalaman dibidang keagamaan akan jauh berbeda karena adanya rasa kedekatan dengan Allah SWT, dan juga siswa dapat membagi waktu dengan baik. Pembentukan karakter dapat dilakukan secara terintegrasi dengan pembentukan kompetensi dalam pendidikan MIPA [17][18][19][35] secara umum dan kimia secara khusus dalam rangka mencetak sumber daya manusia yang handal, berwatak, dan kompetetif [36][37][38][39]. Jadi, pendidikan karakter adalah pendidikan yang didalamnya terdapat suatu tindakan yang mendidik yang sesuai dengan nilai-nilai moral agar terbentuk karakter yang baik atau karakter yang positif yang dapat berguna bagi diri sendiri, masyarakat, budaya dan bangsa. Selain merupakan program pemerintah, full day school merupakan bagian dari penguatan karakter siswa. Dengan adanya penerapan full day school yang diterapkan di Sekolah Dasar Negeri 47/ Kota Jambi sekolah dapat memantau kegiatan keagamaan siswa. Sebelum diterapkannya full day school di sekolah dasar negeri 47/Kota Jambi sekolah tidak dapat memantau kegiatan keagamaan siswa di karenakan jadwal pulang sekolah siswa yang terkadang pulang sebelum jam 12.30 atau sebelum dzuhur. Dengan adanya penerapan full day school siswa pulang jam 15.30 jadi sekolah dapat memantau kegiatan keagamaan siswa.

Berdasarkan hasil observasi tentang penerapan full day school dalam membentuk karakter religius siswa sekolah dasar negeri 47/IV Kota Jambi Terlihat dari Merayakan hari besar keagamaan seperti Isra Mi'raj, tahun baru Islam dan hari besar keagamaan lainnya. (1) Pada tanggal 10 September 2018 Sekolah Dasar Negeri 47/IV Kota Jambi merayakan tahun baru islam 1440 H, yang diikuti dari kelas 3 sampai kelas 6 dengan jumlah siswa yang hadir sebanyak 878 dari jumlah siswa keselurahan sebanyak 1.195. Adapun tujuan dari perayaan tahun baru islam $1440 \mathrm{H}$ yaitu mengenalkan siswa terhadap kalender islam dan memupuk jiwa islami dan kemandiriin siswa. pada perayaan ini siswa mengenakan seragam profesi sesuai dengan citacitanya tujuannya agar siswa termotivasi untuk lebih giat belajar mencapai cita-cita. (2) memiliki fasilitas yang dapat digunakan untuk beribadah, seperti tersedianya Musholla untuk ibadah agama islam melakukan Sholat berjamaah dan tersedia tempat beribadah untuk agama kristen untuk pembacaan al-kitab dan kebaktian. (3) memberikan kesempatan kepada semua siswa untuk beribadah baik agama islam maupun agama kristen. (4) siswa berdo'a sebelum dan sesudah pembelajaran (5) Metode Pembiasaan Menghapal, Adapun pembiasaan yang dilakukan oleh pihak sekolah dalam mengupayakan kebiasaan-kebiasaan menghapal kepada siswa dengan cara tilawah, murajaah, sholat dhuha disekolah dan setiap jam pembelajaran agama siswa menyetor hapalan surat-surat pendek. (6) menyediakan taman pendidikan Al-Qur'an untuk siswa.

\section{KESIMPULAN}

Berdasarkan hasil penelitian dan pembahasan tentang Analisis Penerapan Full day School Dalam Membentuk Karakter Religius Siswa Sekolah Dasar, dapat disimpulkan bahwa Sekolah Dasar Negeri 47/IV Kota Jambi telah menerapkan full day school 2 tahun belakangan ini tepatnya pada tahun 2017. Sekolah Dasar Negeri 47/IV Kota Jambi merupakan salah satu piloting yang ditunjuk oleh pemerintah pusat untuk melaksanakan program penguatan karakter sejak tahun 2017. Full Day School ini merupakan bagian dari penguatan karakter, di Sekolah Dasar Negeri 47/IV kota jambi menerapkan 5 karakter yaitu Religius, Mandiri, Gotong Royong, Nasionalis dan integritas dan sudah ada SK dari pemerintah. Dengan adanya penerapan full day school maka sekolah dapat memantau kegiatan keagamaan siswa seperti Sholat, Pengajian Siswa, Tahfiz, Pembacaan AL-kitab dan lain sebagainya.

\section{UCAPAN TERIMA KASIH}

Peneliti mengucapkan terima kasih kepada kepala sekolah dan guru serta siswa yang telah memberikan izin kepada para peneliti untuk melakukan penelitian ini. khususnya untuk SDN 47/IV Kota Jambi.

\section{REFERENSI}


[1] Asrial, Syahrial, D. A. Kurniawan, R. Septiasari, "Hubungan Kompetensi Pedagogik Dengan Kompetensi IPA Mahasiswa Pendidikan Guru Sekolah Dasar,” Pedagogia: Jurnal Penididikan, vol. 8, no. 2, pp. 149-157, 2019

[2] J. M. Asmani, Full Day School Konsep Manajemen \& Quality Control. Yogyakarta: Ar-ruzz Media, 2017.

[3] Yudefrizal. Dampak Sistem Full Day School Terhadap Prestasi Belajar. Yogyakarta: Penerbit Gaya Media, 2017.

[4] Baharudin, Pendidikan dan Psikologi Perkembangan. Yogyakarta: Ar-Ruzz Media, 2010.

[5] N. Mohammad, Ghazali, and H. Hashim, "Secondary school students' perceptions on the use of Google+ towards improving ESL writing skills," International Journal of Emerging Technologies in Learning, vol. 13, no. 9, pp. 224-238, 2018.

[6] M. Danil, "Implementasi Full Day School di Sekolah Dasar Sabbihisma Padang," Jurnal Komunikasi Pendidikan, vol. 2, no. 1, pp. 86-92, 2018.

[7] E. A. Gamie, M. S. A. El-Seoud, M. A. Salama, and W. Hussein, "Multi-dimensional analysis to predict students' grades in higher education," International Journal of Emerging Technologies in Learning, vol. 14, no. 2, pp. 4-15, 2019.

[8] Kemendiknas, Bahan Pelatihan: Penguatan Metodologi Pembelajaran Berdasarkan Nilai-Nilai Budaya Untuk Membentuk Daya Saing dan Karakter Bangsa. Jakarta: Kemendiknas, 2010.

[9] A. G. Wicaksono, "Fenomena Full Day School dalam Sistem Pendidikan," Komunikasi Pendidikan, vol. 1, no. 1, pp .10-18, 2017.

[10] E. Wulandari, M. Taufik, and K. Kuncahyono, "Analisis Implementasi Full Day School sebagai Upaya Pembentukan Karakter Siswa di SD Muhammadiyah 4 Kota Malang," JP2SD (Jurnal Pemikiran dan Pengembangan Sekolah Dasar), vol. 6, no. 1, pp. 65-74, 2018.

[11] S. Syahrial, A. Asrial, D. A. Kurniawan, P. Nugroho, R. Septiasari, R. A. Pratama, and R. Perdana, "Increased Behavior of Students' Attitudes to Cultural Values Using the Inquiry Learning Model Assisted Ethno constructivism," Journal of Educational Science and Technology (EST), vol. 5, no. 2, pp. 166-175, 2019

[12] M. Leasa, and J. R. Batlolona, "Full day school dalam pembentukan karakter siswa SMKN 13 kota Malang," Jurnal Ilmu Sosial dan Humaniora, vol. 6, no. 1, pp. 73-82, 2017.

[13] A. Astalini, D. A. Kurniawan, D. K. Sari, and W. Kurniawan, "description of science normality, attitudes of investigation career on physics in senior high school" JIPF (Jurnal Ilmu Pendidikan Fisika), vol. 3, no. 2, 2019

[14] S. Suranto and Suharningsih, Pengaruh Sistem Full Day School Terhadap Hasil Belajar Siswa. Bandung: PT Remaja Rosdakarya, 2017.

[15] A. Asrial, S. Syahrial, D. A. Kurniawan, F. Chan, P. Nugroho, R. A. Pratama, and R. Septiasari, "Identification: The Effect Of Mathematical Competence On Pedagogic Competency Of Prospective Teacher," Humanities \& Social Sciences Reviews (HSSR), vol. 7, no. 4, pp. 85-92, 2019.

[16] T. Mairisiska, Sutrisno, and Asrial, "Pengembangan Perangkat Pembelajaran Berbasis TPACK pada Materi Sifat Koligatif Larutan untuk Meningkatkan Keterampilan Berpikir Kritis Siswa,” EDU Sains, vol. 3, no. 1, pp. 28-37, 2014

[17] L. J. Moleong, Metodologi Penelitian Kualitatif. Bandung: PT Remaja Rosdakarya, 2017.

[18] Sugiyono, Metode Penelitian Kombinasi (Mixed Methods). Bandung: Alfabeta, 2018.

[19] D. A. Kurniawan, A. Astalini, D. Darmaji, and R. Melsayanti, "Students' attitude towards natural sciences," Int. J. Eval. \& Res. Educ, vol 8, no. 3, pp. 455-460, 2019.

[20] A. Astalini, D. A. Kurniawan, R. Perdana, and H. Pathoni, "Identifikasi Sikap Peserta Didik Terhadap Mata Pelajaran Fisika di Sekolah Menengah Atas Negeri 5 Kota Jambi” Unnes Physics Education Journal, vol. 8, no. 1, pp. 34-43, 2019

[21] Sugiyono, Metodologi Penelitian. Bandung: Alfabeta, 2011.

[22] Astalini, D. Darmaji, W. Kurniawan, K. Anwar, and D. A. Kurniawan. " Effectivenes of Using E-Module and EAssessment," International Journal of Interactive Mobile Technologies (iJIM), vol. 13 no. 9, pp. 21-39, 2019.

[23] D. Darmaji, D. A. Kurniawan, A. Astalini, and N. R. Nasih. "Persepsi Mahasiswa pada Penuntun Praktikum Fisika Dasar II Berbasis Mobile Learning," Jurnal Pendidikan: Teori, Penelitian, dan Pengembangan, vol. 4 no. 4, pp.516-523, 2019.

[24] Daryanto and Darmiatun, Implementasi Pendidikan Karakter di Sekolah. Yogyakarta: Penerbit Gaya Media, 2013.

[25] Astalini, et al. "Motivation and Attitude of Students on Physics Subject in The Middle School in Indonesia," International Education Studies (IES) Journal, vol. 12 no. 9, pp. 15-26, 2019.

[26] Asrial, Syahrial, D. A. Kurniawan, Maryono, P. Nugroho, and R. Perdana. "Etno-social Knowledge: How Does Knowledge of Basic School Teachers in Indonesia?," Journal of Education and Learning (EduLearn), vol. 13 no. 4, pp. 583-588, 2019.

[27] D. S. Putra, and O. H. Wiza, "Analisis Sikap Siswa terhadap Mata Pelajaran Fisika di SMA Ferdy Ferry Putra Kota Jambi," UPEJ Unnes Physics Education Journal, vol. 8, no. 3, pp. 299-311, 2019.

[28] W. Kurniawan, et al. "Multimedia Physics Practicum Reflective Material Based on Problem Solving for Science Process Skills," International Journal of Evaluation and Research in Education (IJERE), vol. 8 no. 4, pp. 590-595, 2019.

[29] A. Asrial, S. Syahrial, D. A. Kurniawan, R. Perdana, and P. Nugroho. "Supporting Technology 4.0: Ethnocontructivist Multimedia for Elementary Schools," International Journal of Online and Biomedical Engineering (iJOE), vol. 15 no. 14, pp. 54-66, 2019.

[30] A. Astalini, D. Darmaji, D. A. Kurniawan, and A. Destianti, "Description of the Dimensions Attitudes towards Science in Junior High School at Muaro Jambi," International Journal of Sciences: Basic and Applied Research (IJSBAR), vol. 47, no. 1, pp. 1-11, 2019. 
[31] D. S. Putra, A. Lumbantoruan, and S. C. Samosir, "Deskripsi Sikap Siswa: Adopsi Sikap Ilmiah, Ketertarikan Memperbanyak Waktu Belajar Fisika dan Ketertarikan Berkarir dibidang Fisika," Tarbiyah: Jurnal Ilmiah Kependidikan, vol. 8, no. 2, pp. 91-100, 2019.

[32] D. A Kurniawan, A. Astalini, and L. Anggraini, "Evaluasi Sikap Siswa Smp Terhadap Ipa Di Kabupaten Muaro Jambi," Jurnal Ilmiah DIKDATIKA, vol. 19, no. 1, pp. 124-139, 2018

[33] A. Astalini, D. A. Kurniawan, and S. Sumaryanti, "Sikap Siswa Terhadap Pelajaran Fisika di SMAN Kabupaten Batanghari," JIPF (Jurnal Ilmu Pendidikan Fisika), vol. 3, no. 2, pp. 59-64, 2018

[34] D. Darmaji, A. Astalini, D. A. Kurniawan, and R. Perdana, "A study relationship attitude toward physics, motivation, and character discipline students senior high school, in Indonesia," International Journal of Learning and Teaching, vol. 11, no. 3, pp. 99-109, 2019

[35] D. Darmaji, A. Astalini, D. A. Kurniawan, H. Parasdila, I. Irdianti, S. Susbiyanto, K. Kuswanto, and M. Ikhlas. "EModule Based Problem Solving in Basic Physics Practicum for Science Process Skills," International Journal of Online and Biomedical Engineering (iJOE), vol. 15, no. 15, pp. 4-17, 2019

[36] Astalini, D. A. Kurniawan, Darmaji, L. R. Sholihah, and R. Perdana. "Characteristics of Students' Attitude to Physics in Muaro Jambi High School,” Humanities \& Social Sciences Reviews (HSSR), vol. 7 no. 2, pp. 91-99, 2019.

[37] A. Asrial, S. Syahrial, D. A. Kurniawan, and N. Amalina. "Analisis Hubungan Kompetensi Bahasa Indonesia Terhadap Kompetensi Pedagogik Mahasiswa Pendidikan Guru Sekolah Dasar," Premier Educandum: Jurnal Pendidikan Dasar dan Pembelajaran, vol 9 no. 1, pp. 1-8, 2019.

[38] Astalini, Darmaji, D. A. Kurniawan, and A. Destianti. "The Relationship Between Learning Independence and Attitude Toward Science for Junior High School Students," Jurnal Pendidikan Progresif, vol. 9 no. 2, pp.123-131, 2019.

[39] Darmaji, et al. "E-Module Based Problem Solving in Basic Physics Practicum for Science Process Skills," International Journal of Online and Biomedical Engineering (iJOE), vol. 15 no. 15, pp. 4-17, 2019. 